\title{
Sympathetic and parasympathetic innervation in hepatocellular carcinoma
}

\author{
L. ZHANG ${ }^{1, \neq}$, L. L. WU ${ }^{1, \neq}$, H. B. HUAN ${ }^{1}$, X. J. $\mathrm{CHEN}^{2}$, X. D. WEN ${ }^{1}$, D. P. YANG ${ }^{1}$, F. XIA ${ }^{1, *}$ \\ ${ }^{1}$ Institute of Hepatobiliary Surgery, Southwest Cancer Center, Southwest Hospital, Third Military Medical University, Chongqing, China; ${ }^{2}$ Institute \\ of Pathology and Southwest Cancer Center, Southwest Hospital, Third Military Medical University, Chongqing, China \\ *Correspondence: txzzxf@163.com \\ ${ }^{*}$ Contributed equally to this work.
}

Received December 17, 2016 / Accepted March 21, 2017

\begin{abstract}
Autonomic nervous system plays an important role in the development of multiple cancers via regulating cancer cell proliferation, differentiation, apoptosis, migration and invasion. However, no detailed studies have been performed to study the role of autonomic nerve fibers in hepatocellular carcinoma (HCC) as well as its correlation with the progression of HCC. Here, we examined the distribution of the autonomic nerve fibers and analyzed the correlation between autonomic nerve fibers and the pathological characteristics of HCC patients. The transcriptional expression of adrenergic and cholinergic receptors was evaluated in both hepatoma cell lines and primary hepatoma cells. In addition, we summarized the function of receptors for neurotransmitters in different cancers recently reported. Our findings indicate that tissue of liver cancer is innervated by both sympathetic and parasympathetic nerves and the density of the nerve fibers is associated with patients' poor prognosis. Additionally, we report that adrenergic receptors $\beta 2$ and cholinergic receptors $\alpha 7, \mathrm{M} 1$ and M3 are high expressed in both hepatoma cell lines and primary hepatoma cells, indicating these receptors may play essential roles in the regulation of autonomic nervous system triggered HCC.
\end{abstract}

Key words: hepatocellular carcinoma (HCC), sympathetic innervation, parasympathetic innervation, receptors for neurotransmitters

Accumulated evidences have indicated that the autonomic nervous system modulates the progression of tumorigenesis and metastases $[1,2]$. Furthermore, it is believed that the nervous system influence tumor development directly by activating receptors on cancer cells or regulation of tumor microenvironment indirectly [3]. Innervation of tumors has been confirmed in various experimental models and in human tumors [4-6]. For example, it demonstrated that nicotine could promote metastasis of pancreatic cancer through nicotinic acetylcholine receptor $a 7$ [7]. Recent retrospective clinical data suggest that patients with breast cancer, melanoma, or prostate cancer taking $\beta$-blockers had lower recurrence rate and mortality $[8,9]$. Meanwhile, some studies have shown that patients who underwent vagotomy exhibited a decreased in the risk of stomach cancer, while other studies showed an increased risk $[2,10]$. So the effect of vagotomy on cancer incidence is still needed to be verified.

Liver cancer is one of the most common malignant tumors in China, and the second leading cause of cancer-related deaths [11]. The liver is abundantly innervated by the sympathetic and parasympathetic nerve fibers, controlling growth and maintenance of the liver glands [3]. However, the innervation in HCC has not yet been completely characterized.

Thus, the aim of the present study was to investigate the distribution of the autonomic fibers in HCC and the expression of adrenergic and cholinergic receptors within normal liver cell and twelve types of hepatoma cells. Firstly, we found that the innervation by autonomic fibers was correlated with HCC patients' prognosis. And then we investigated the expression of receptors for neurotransmitters in 12 kinds of hepatoma cells derived from humans and analyzed their expression differences. The adrenergic receptors $\beta 2$ and cholinergic receptors $\alpha 7, \mathrm{M} 1$ and M3 were found playing important roles. Our study could provide more proofs for studying the role of autonomic nervous system in HCC.

\section{Materials and methods}

Cell culture. Hepatoma cell lines, including HepG2, SMMC-7721, SMMC-7404, PLC and Huh7 were purchased 
from ATCC (Manassas, VA, USA). MHCC-97H and normal human hepatic cell L02 were purchased from Chinese Academy of Sciences (Shanghai, China). Primary hepatoma cells (T127, T420, T421, T1115, T1224, and as408, which were derived from the HCC patients), were generously given by Professor Qian cheng, from the Institute of Pathology and Southwest Cancer Center [12]. Especially, as408, T421 and T127 were derived from liver cancer patients with portal venous tumor emboli. All the cell-lines were cultured in high glucose Dulbecco's modified Eagle's medium (H-DMEM, Gibco, USA) and supplemented with $10 \%$ fetal bovine serum (FBS, Gibco) at $37{ }^{\circ} \mathrm{C}$ in a humidified incubator containing $5 \% \mathrm{CO}_{2}$.

Patients and specimens. A total of 30 paraffin-embedded archived HCC specimens were obtained from the Institute of Hepatobiliary Surgery, Southwest Hospital, Third Military Medical University. Ten HCC cases with matched adjacent non-cancerous normal liver tissues were collected and stored in liquid nitrogen for protein extraction routinely. All the specimens were collected with informed consent according to protocols approved by the Institution Ethics Committee of the Southwest Hospital.

Tissue protein extraction and western blot assay. The total protein of the ten HCC samples was extracted using tissue protein extraction Kit (CWBIO, China), and the concentration of proteins was determined by BCA Protein Assay (BOSTER, China). Total protein of each sample was electrophoresed in $10 \%$ sodium dodecyl sulphate-polyacrylamide gradient mingle (SDS-PAGE gel) and electro-transferred onto nitrocellulose membranes with Mini-Genie blotting system (Bio-Rad). After blocking for $2 \mathrm{~h}$ at room temperature $\left(22^{\circ} \mathrm{C} \sim 25^{\circ} \mathrm{C}\right)$, the western blots were probed with primary antibodies against tyrosine hydroxylase (TH) (1:2000; Abcam; USA) and vesicular acetylcholine transporter (VAChT) (1:2000; Abcam; USA) for $12 \mathrm{~h}$ in $4{ }^{\circ} \mathrm{C}$ and with secondary antibody for $2 \mathrm{~h}$ at room temperature. Finally, the protein bands were detected by enhanced chemiluminescence (BioRad). The experiments were repeated three times.

Immunohistochemical (IHC) analysis. Immunohistochemistry was performed using an Envision Kit (Dako) according to manufacturer's protocol. Briefly, the tissue sections were incubated with anti-tyrosine hydroxylase $(\mathrm{TH})$ antibody (1:1000; Abcam; USA) and anti-vesicular acetylcholine transporter (VAChT) antibody (1:1000; Abcam; USA) overnight at $4^{\circ} \mathrm{C}$. The sympathetic and parasympathetic fibers were identified by TH and VAChT respectively [1]. On the following day, the tissue sections were incubated with secondary antibody for $1 \mathrm{~h}$ at room temperature. The immunostained tissue sections were visualized using liquid $\mathrm{DAB}$ substrate (Thermo Scientific; Waltham, MA, USA). After immunostaining, the tissue sections were immersed in hematoxylin for nuclear staining. The immunostaining results were independently evaluated by two pathologists who were blinded to the sample sources, based on the intensity of positively stained areas [13]. The intensity of stained areas classified as negative
$(-)$, weak $(+)$, moderate $(++)$, or strong $(+++)$. Sections with negative and weak expression of TH and VAChT were designated as low expression group, whereas those with moderate and strong expression group were classified as high expression group. We analyzed five representative staining fields of each tumor sample. $P<0.05$ was considered significant.

RNA isolation and real time-polymerase chain reaction (RT-PCR). Total cellular RNA was extracted from cultured cells $\left(\sim 1 \times 10^{6}\right.$ cells) using the Trizol reagent (TaKaRa, Japan) according to the manufacturer's instructions. The reverse transcription was conducted in a reaction volume of $20 \mu \mathrm{L}$ with a reverse transcription (RT) system kit (TaKaRa, Japan). PCR reactions were carried out involving an initial denaturation step at $95{ }^{\circ} \mathrm{C}$ for 10 minutes, followed by 45 cycles of denaturation $\left(95^{\circ} \mathrm{C}\right.$ for $\left.10 \mathrm{~s}\right)$, annealing $\left(55^{\circ} \mathrm{C}\right.$ for $\left.15 \mathrm{~s}\right)$, and extension $\left(75^{\circ} \mathrm{C}\right.$ for $\left.15 \mathrm{~s}\right)$. Primers were used to amplify glyceraldehyde-3-phosphate dehydrogenase (GAPDH), muscarinic acetylcholine receptors (mAChR) M1 M5, nicotinic acetylcholine receptors (nAChR) $\alpha 1 \sim \alpha 7, \alpha 9 \sim \alpha 10, \beta 2 \sim \beta 4$ and adrenergic receptors (ARs) $\alpha 1 \mathrm{~A}, \alpha 1 \mathrm{~B}, \alpha 1 \mathrm{D}, \alpha 2 \mathrm{~A}, \alpha 2 \mathrm{~B}, \alpha 2 \mathrm{C}$, $\beta 1 \sim \beta 3$ (Table 1).

Statistical analysis. All the measurement data are presented as the mean \pm SEM. The chi-square test was used to analyze the relationship between TH and VAChT expression and clinicopathological features, and a value of $P<0.05$ was considered to be statistically significant difference. Radar map and pie chart were drawn in Excel 2007 according to the expression of receptors for neurotransmitters. Survival curves were plotted by the Kaplan-Meier method and compared using the log-rank test. All analyses were performed with SPSS version 21.0 (SPSS, Inc., Chicago, IL, USA).

\section{Results}

Innervation of sympathetic and parasympathetic nerve fibers and correlation with the prognosis in HCC patients. To determine the distribution of the sympathetic and parasympathetic fibers in HCC, IHC analysis was performed in 30 paraffin-embedded HCC tissue samples. As shown in Figure 1A, high levels of $\mathrm{TH}$ were present in cancerous lesions in the primary HCC tumors while weak expression was detected in non-cancer liver tissues. Consistently, there was higher expression of VAChT in tumor tissues than non-cancer liver tissues (Figure 1B). Furthermore, the possible correlation between TH or VAChT and clinical features of HCC was also determined. The results showed that both TH and VAChT were correlated with serum AFP levels $(P<0.05)$, lymphatic metastasis $(P<0.05)$, clinical stage $(P<0.05)$ and vascular invasion $(P<0.05$, Table 2$)$. TH expression also correlated with recurrence $(P=0.047)$, while VAChT $\operatorname{did} \operatorname{not}(P>0.05)$. However, there were no significant associations between those two proteins and other clinical features such as gender, hepatitis history, tumor size and age. Using Kaplan-Meier analysis and the log-rank test, we determined the effect of TH and VAChT expression on survival. The results showed that patients with 
Table 1. Primer sequences and product sizes

\begin{tabular}{|c|c|c|}
\hline Gene & Primer sequence & $\begin{array}{l}\text { Product } \\
\text { size (bp) }\end{array}$ \\
\hline \multirow[t]{2}{*}{ nAChRál } & Forward: GCTCTGTCGTGGCCATCAA & 70 \\
\hline & Reverse: CACTCCCCGCTCTCCATG & \\
\hline \multirow[t]{2}{*}{ nAChRá2 } & Forward: GTGGAGGAGGAGGACAGA & 155 \\
\hline & Reverse: CTTCTGCATGTGGGGTGATA & \\
\hline \multirow[t]{2}{*}{ nAChRá3 } & Forward: AACCTGTGGCTCAAGCAAATCT & 78 \\
\hline & Reverse: CATGAACTCTGCCCСACCAT & \\
\hline \multirow[t]{2}{*}{ nAChRá4 } & Forward: GTGGATGAGAAGAACCAGATGATG & 74 \\
\hline & Reverse: CAGCGCAGCTTGTAGTCGTG & \\
\hline \multirow[t]{2}{*}{ nAChRá5 } & Forward: AGATGGAACCCTGATGACTATGGT & 104 \\
\hline & Reverse: AAACGTCCATCTGCATTATCAAAC & \\
\hline \multirow[t]{2}{*}{ nAChRá6 } & Forward: TGGCCAACGTGGATGAAGTAA & 111 \\
\hline & Reverse: TCTCAATGCCATCATATTCCATTG & \\
\hline \multirow[t]{2}{*}{ nAChRá7 } & Forward: GCTGCTCGTGGCTGAGATC & 68 \\
\hline & Reverse: TGGCGAAGTACTGGGCTATCA & \\
\hline \multirow[t]{2}{*}{ nAChRá9 } & Forward: AAAGATGAACTGGTCCCATTCCT & 118 \\
\hline & $\begin{array}{l}\text { Reverse: AAGGTCATTAAACAACTTCTGAG- } \\
\text { CATAT }\end{array}$ & \\
\hline \multirow[t]{2}{*}{ nAChRá10 } & Forward: TGCCTATGGTGGCCTGGAT & 103 \\
\hline & Reverse: GGCGGAACCTGGAGGCT & \\
\hline \multirow[t]{2}{*}{ nAChRâ2 } & Forward: CTGGATCCTTCCCGCTACAAC & 146 \\
\hline & Reverse: TGGGTCAGCCAGACATTGGT & \\
\hline \multirow[t]{2}{*}{ nAChRâ3 } & Forward: CCTCCGTTTGTTTTCTTTTCATAAT & 148 \\
\hline & Reverse: TTCGTCCAGACAGACTTTTCATTTT & \\
\hline \multirow[t]{2}{*}{ nAChRâ4 } & Forward: TCACAGCTCATCTCCATCAAGCT & 100 \\
\hline & Reverse: CCTGTTTCAGCCAGACATTGGT & \\
\hline \multirow[t]{2}{*}{ mAChRM1 } & Forward: TGACCGCTACTTCTCCGTGACT & 109 \\
\hline & Reverse: CCAGAGCACAAAGGAAACCA & \\
\hline \multirow[t]{2}{*}{ mAChRM2 } & Forward: TCACAAAACCTCTGACCTACCC & 142 \\
\hline & Reverse: TCCACAGTTCTCСАСССТАСАA & \\
\hline \multirow[t]{2}{*}{ mAChRM3 } & Forward: ACCATCCСТCAАСТCСАCСAAGT & 138 \\
\hline & Reverse: GGAAAACTGCCTCCATCGTC & \\
\hline \multirow[t]{2}{*}{ mAChRM4 } & Forward: TCGCTATGAGACGGTGGAAA & 695 \\
\hline & Reverse: GCTTCTTGACGCTCTGCTTCATTAG & \\
\hline \multirow[t]{2}{*}{ mAChRM5 } & Forward: GAAAGCAGCCCAGACACTGA & 140 \\
\hline & Reverse: AGCACAACCAACAGCCCAAG & \\
\hline \multirow[t]{2}{*}{ á1A-AR } & Forward: GTGAACATTTCCAAGGCCATT & 636 \\
\hline & Reverse: TCACTTGCTCCGAGTCCGACTT & \\
\hline \multirow[t]{2}{*}{ álB-AR } & Forward: AАСССТТСТАТGСССТСТТСТССТС & 204 \\
\hline & Reverse: TACTGCTAAGGGTGTCCTCGTGAAA & \\
\hline \multirow[t]{2}{*}{ álD-AR } & Forward: AGCGCTTCTGCGGTATCA & 68 \\
\hline & Reverse: CAGGTAGAAGGAGCACACGG & \\
\hline á2A-AR & Forward: CAGGCCATCGAGTACAACCT & 183 \\
\hline & Reverse: GACGTACCACTTCTGGTCGT & \\
\hline á2B-AR & Forward: CCTGGCCTCCAGCATCGGAT & 612 \\
\hline & Reverse: ATGACCACAGCCAGCACGAA & \\
\hline á2C-AR & Forward: GTGGTGATCGCCGTGCTGAC & 573 \\
\hline & Reverse: CGTTTTCGGTAGTCGGGGAC & \\
\hline âl-AR & Forward: CGCCTCTTCGTCTTCTTCAACTG & 236 \\
\hline & Reverse: ACATCGTCGTCGTCGTCGTC & \\
\hline â2-AR & Forward: GTGATCGCAGTGGATCGCTA & 175 \\
\hline & Reverse: AGTTGATGGCTTCCTGGTGG & \\
\hline â3-AR & Forward: CAATACCGCCAACACCAGTGGG & 151 \\
\hline & Reverse: GGTCATGGTCTGGAGTCTCG & \\
\hline GAPDH & Forward: AGAAGGCTGGGGCTCATTTG & 258 \\
\hline & Reverse: AGGGGCCATCCACAGTCTTC & \\
\hline
\end{tabular}

high TH and VAChT expression had shorter survival times, whereas those with low TH and VAChT expression had longer survival times (Figure 1C and 1D). Taken together, these results indicate that sympathetic and parasympathetic innervation strongly correlated with the progression of HCC.

To further verify the different expression of TH and VAChT, total proteins of liver cancer tissues and paired non-cancer tissues of 10 HCC patients were extracted and conducted western blot assay. It was observed that the expression of $\mathrm{TH}$ and VAChT were increased in liver tumor tissues as compared to non-tumor liver tissues in HCC patients (Figure 1E), which was in accordance with IHC results. Consequently, we suggested that the autonomic fibers are abundant in tumor tissues, and there must be correlation between their distribution and the progression of HCC through their specific neural transmitters and corresponding receptors.

Expression of adrenergic and cholinergic receptors in liver cancer cells. As the effects of sympathetic and parasympathetic nerves on liver are executed through activating

Table 2. Correlation between TH and VAChT expression and clinicopathological characteristics of HCC patients

\begin{tabular}{|c|c|c|c|c|c|c|c|}
\hline \multirow{2}{*}{ Characteristics } & \multirow{2}{*}{$\begin{array}{c}\text { Cas- } \\
\text { es }\end{array}$} & \multicolumn{2}{|c|}{ TH } & \multirow{2}{*}{$\begin{array}{c}\mathrm{P} \\
\text { value }\end{array}$} & \multicolumn{2}{|c|}{ VAChT } & \multirow{2}{*}{$\begin{array}{c}\mathrm{P} \\
\text { value }\end{array}$} \\
\hline & & Low & High & & Low & High & \\
\hline Gender & & & & 0.393 & & & 0.563 \\
\hline male & 28 & 11 & 17 & & 9 & 19 & \\
\hline female & 2 & 0 & 2 & & 1 & 1 & \\
\hline Age (years) & & & & 0.279 & & & 0.344 \\
\hline$<48$ & 18 & 8 & 10 & & 5 & 13 & \\
\hline$\geq 48$ & 12 & 3 & 9 & & 5 & 7 & \\
\hline Recurrence & & & & 0.047 & & & 0.191 \\
\hline Yes & 25 & 7 & 18 & & 7 & 18 & \\
\hline No & 5 & 4 & 1 & & 3 & 2 & \\
\hline Vascular invasion & & & & 0.026 & & & 0.038 \\
\hline Yes & 14 & 2 & 12 & & 2 & 12 & \\
\hline No & 16 & 9 & 7 & & 8 & 8 & \\
\hline Hepatitis history & & & & 0.258 & & & 0.344 \\
\hline Yes & 21 & 9 & 12 & & 8 & 13 & \\
\hline No & 9 & 2 & 7 & & 2 & 7 & \\
\hline Lymphatic metastasis & & & & 0.04 & & & 0.011 \\
\hline Yes & 13 & 2 & 11 & & 1 & 12 & \\
\hline No & 17 & 9 & 8 & & 9 & 8 & \\
\hline $\operatorname{AFP}(\mathrm{ng} / \mathrm{ml})$ & & & & 0.009 & & & 0.041 \\
\hline$<400$ & 8 & 6 & 2 & & 5 & 3 & \\
\hline$\geq 400$ & 22 & 5 & 17 & & 5 & 17 & \\
\hline Tumor size $(\mathrm{cm})$ & & & & 0.397 & & & 0.729 \\
\hline$<5$ & 5 & 1 & 4 & & 2 & 3 & \\
\hline$\geq 5$ & 25 & 10 & 15 & & 8 & 17 & \\
\hline TNM stage & & & & 0.012 & & & 0.03 \\
\hline I & 3 & 3 & 0 & & 3 & 0 & \\
\hline II & 2 & 2 & 0 & & 2 & 0 & \\
\hline III & 17 & 5 & 12 & & 5 & 12 & \\
\hline IV & 8 & 1 & 7 & & 0 & 8 & \\
\hline
\end{tabular}


A

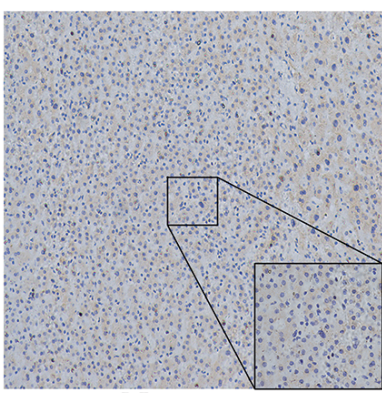

Non-cancer

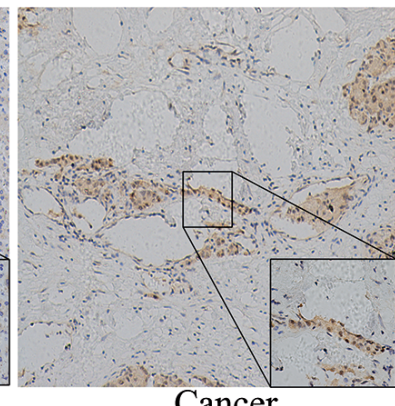

Cancer

B

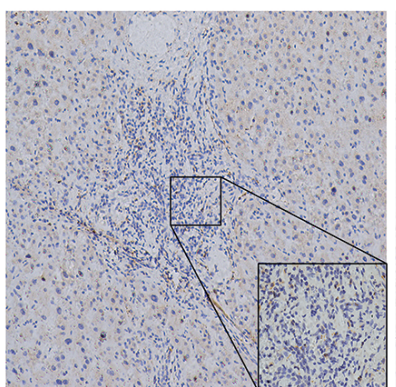

Non-cancer

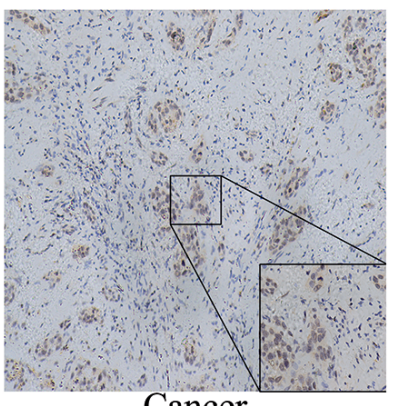

Cancer
C

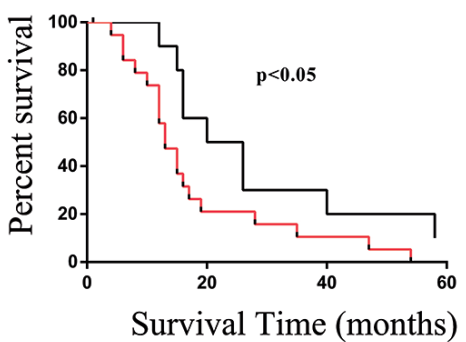

$\mathrm{D}$

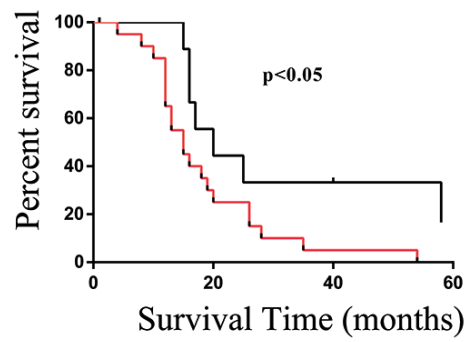

$\mathrm{E}$

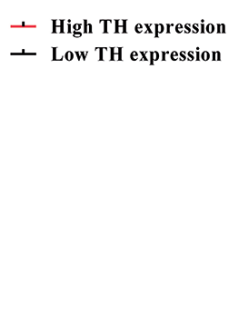

- High VAChT expression - Low VAChT expression

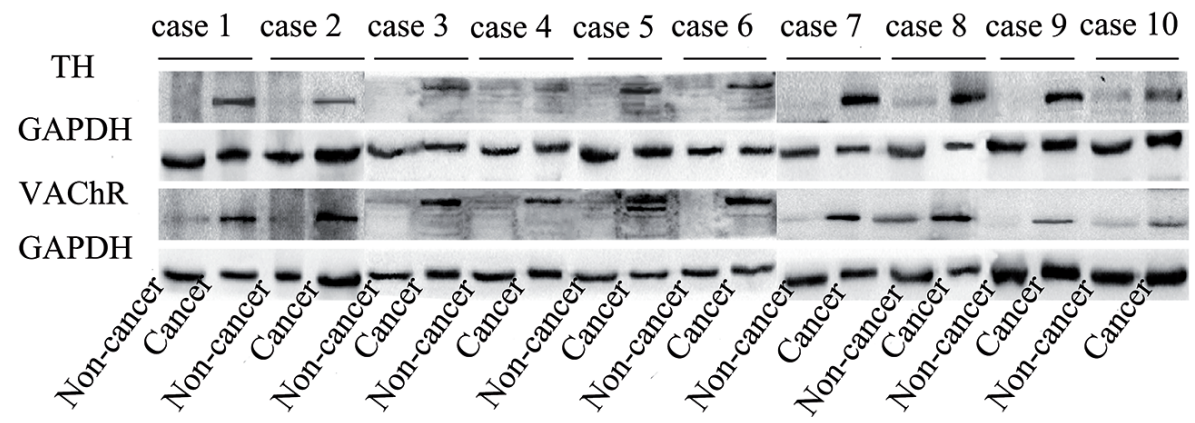

Figure 1. Innervation of sympathetic and parasympathetic nerves in HCC tissues. A and B: Representative images $(100 \times$ and $400 \times)$ from immunohistochemistry analyses of TH and VAChT expression in HCC tissues (Cancer) and matched adjacent non-cancerous tissues (non-Cancer). C and D: The overall survival of HCC patients with high TH and VAChT expression tumors (red lines) versus low TH expressing tumors (bold lines). E: Expression of TH and VAChT proteins in ten HCC patients.

receptors for neurotransmitters by neurotransmitters, it is helpful to investigate the distribution of receptors for neurotransmitters to explore the influence of nervous system on HCC. Therefore, the transcriptional expression of $\alpha 1 \sim \alpha 7$, a9 $110, \beta 2 \sim \beta 4 \mathrm{nAChR}$ subunits, M1, M2, M3, M4, and M5 subtypes of $\mathrm{mAChR}$, and $\alpha 1 \mathrm{~A}, \alpha 1 \mathrm{~B}, \alpha 1 \mathrm{D}, \alpha 2 \mathrm{~A}, \alpha 2 \mathrm{~B}, \alpha 2 \mathrm{C}$, $\beta 1 \sim \beta 3$ subtypes of $A R s$ were investigated in the normal liver cell and hepatoma cells including HepG2, SMMC-7721, SMMC-7404, PLC, Huh7, MHCC-97H, and primary hepatic carcinoma cells T127, T420, T421, T1115, T1224, and as408. By analyzing the expression of the receptors, radar map was drawn to better illustrate the distribution features (Figure 2A). As we can see from these results, all kinds of hepatoma cells expressed different receptors for neurotransmitters. In L02 normal human liver cells, expression of M2 subtypes of mAChRs, $\alpha 5, \alpha 6$ and $\alpha 7$ subunits of nAChRs, and $\beta 2$ adrenergic receptors were detected. In HepG2, SMMC-7721, SMMC-7404, PLC, Huh7 and MHCC-97H hepatoma cells, adrenergic receptors were mainly expressed and cholinergic receptors were relatively weakly detected. For example, SMMC-721 cells predominantly expressed $\beta 2, \alpha 2 \mathrm{~A}$ and $\alpha 1 \mathrm{~A}$ adrenergic receptors. In HepG2 cells, $\beta 2$ adrenergic receptors were mainly detected and M1 and M3 cholinergic receptors were in low expression. In addition, with high invasive ability, MHCC-97H expressed high levels of $\beta 2$ and $\alpha 1 \mathrm{~B}$ adrenergic receptors and M1 cholinergic receptors compared with 
A
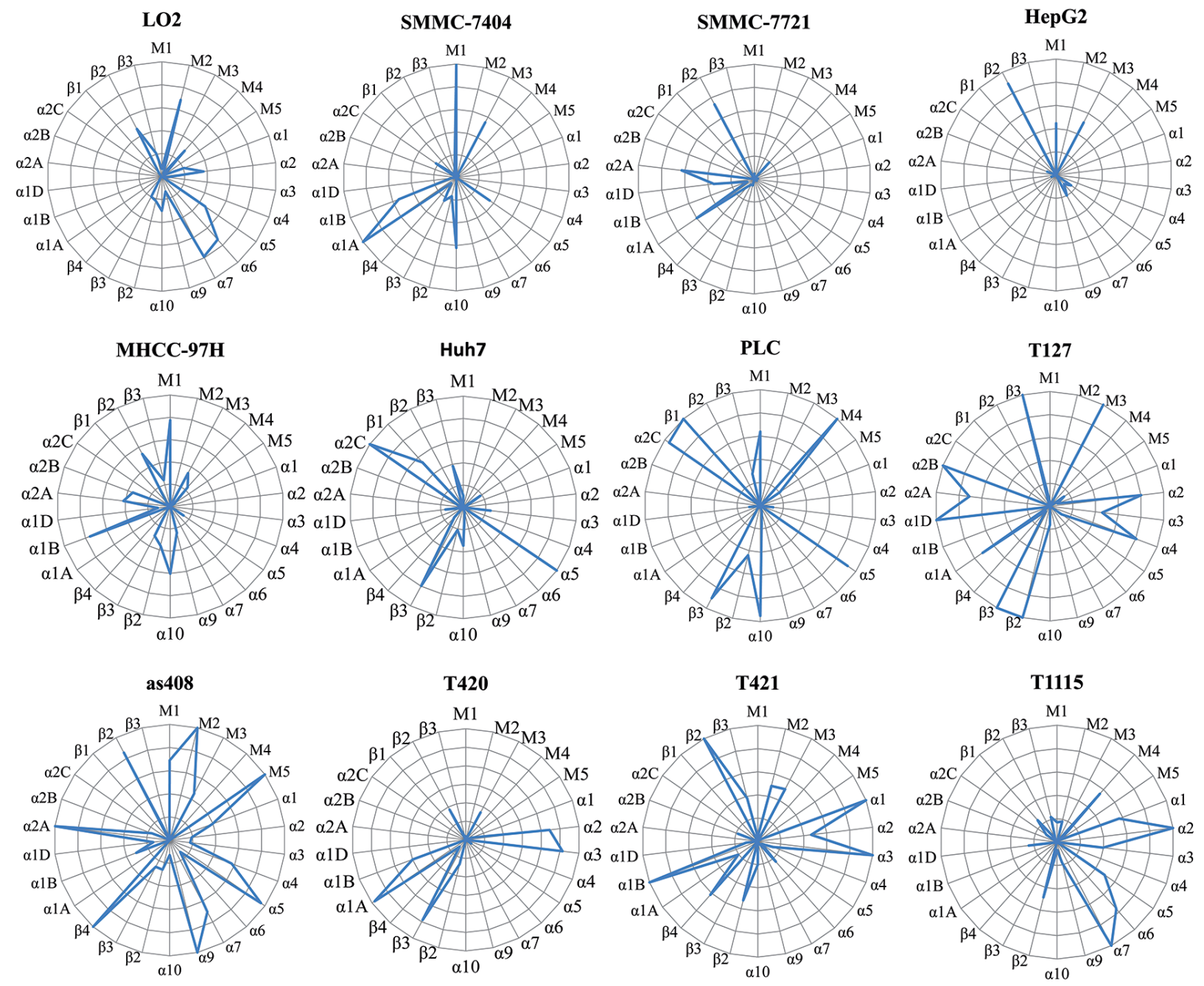

B
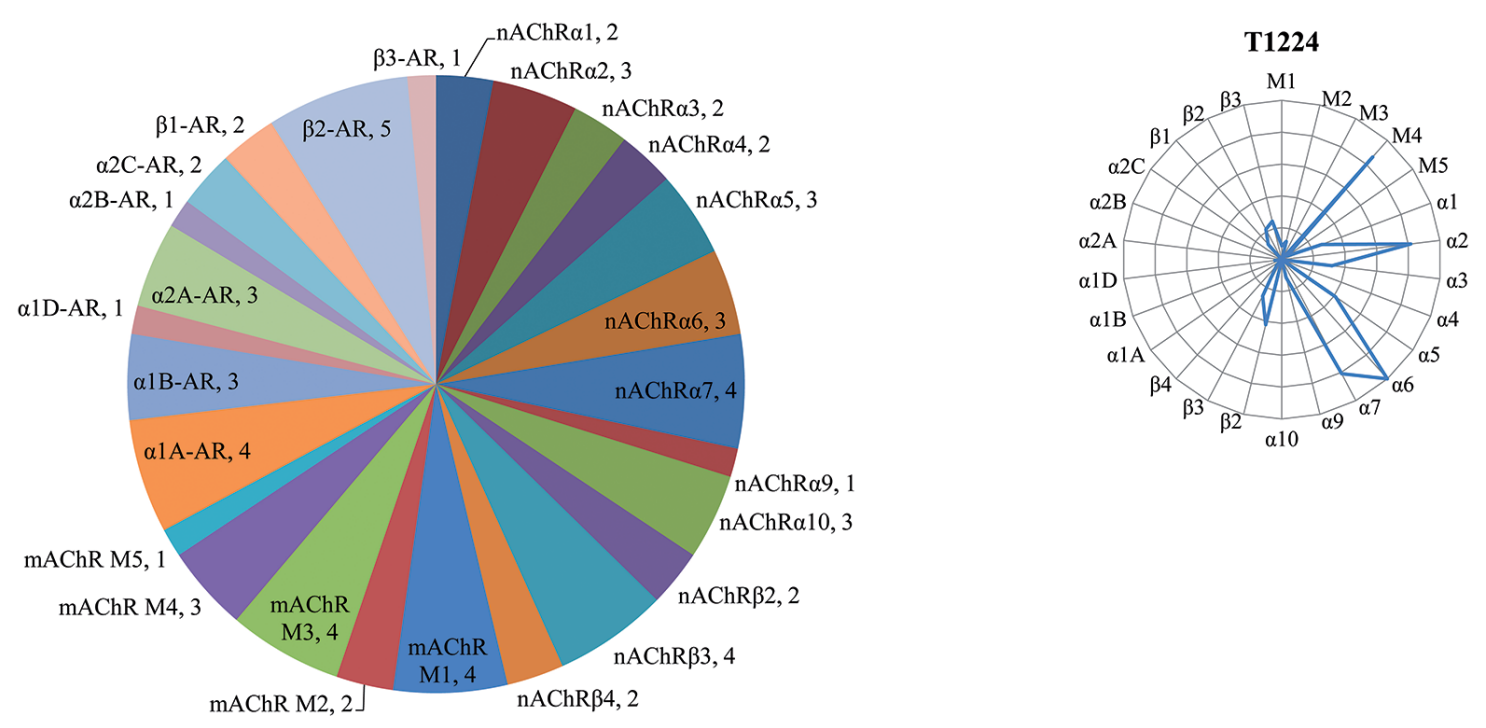

Figure 2. Expression of adrenergic and cholinergic receptors in hepatoma cells. A: Expression of adrenergic and cholinergic receptors of L02 and twelve kinds of hepatoma cells as showed by radar map. The RT-PCR experiment was repeated three times. B: The number of thirteen kinds of cells expressing certain adrenergic or cholinergic receptors. For example, "nAChRa5, 3" represented that nAChRa5 was expressed in three of the thirteen kinds of cells. 
HepG2 cells. However, in primary hepatic carcinoma cells T127, T420, T421, T1115, T1224 and as408, adrenergic and cholinergic receptors were widely expressed. In as 408 , T421 and T127 cells derived from portal venous tumor emboli, which had high malignancy and invasive ability, more kinds of receptors for neurotransmitters expression were found than the other hepatic carcinoma cells. For instance, in as 408 cells, 8 kinds of receptors for neurotransmitters were detected ( $\beta 2$ and $\alpha 2 \mathrm{~A}$ adrenergic receptors and M1, M2, M5, $\alpha 5, \alpha 7$ and $\alpha 9$ cholinergic receptors). While in T1115 cells, only $\alpha 2$, $a 6$ and $\alpha 7$ cholinergic receptors were expressed.

According to the expression levels of adrenergic and cholinergic receptors, we sort out the receptors with high expression (relative expression $>0.5$ ) and made the pie chart (Figure 2B). The results showed that, for example, adrenergic receptors $\beta 2$ was highly expressed in five kinds of cells (SMMC-7721, HepG2, MHCC-97H, as408 and T421). From the chart, we can easily find that the receptors, such as adrenergic receptors $\beta 2, \alpha 1 \mathrm{~A}$ and cholinergic receptors $\alpha 7 \mathrm{nAChR}$ and $\mathrm{M} 1$ and $\mathrm{M} 3$ $\mathrm{mAChRs}$, were expressed in most liver cancer cells, suggesting that these receptors may play a key role in progression of HCC.

\section{Discussion}

Our results have demonstrated that both sympathetic and parasympathetic nerves fibers density is high in HCC and their high distribution correlated with poor prognosis in HCC patients. Additionally, multiple adrenergic and cholinergic receptors were expressed on different kinds of hepatoma cell lines, in which the adrenergic receptors $\beta 2$ and cholinergic receptors $\alpha 7, \mathrm{M} 1$ and M3 were essential for the abilities of hepatoma cells. The different quantities and kinds of receptors for neurotransmitters on hepatoma cells may predict their different capacities, such as proliferation and invasion. In conclusion, the innervation of sympathetic and parasympathetic nerves fibers have significant effects on the progression of HCC.

The nervous system regulates cancer progression in different ways and there is also crosstalk between tumor cells and nerves. Nervous system interacts with immune function, inflammation and microenvironments to influence cancer metastasis through activating specific receptors for neurotransmitters $[3,5]$. Our results showed that the high expression of $\mathrm{TH}$ and VAChT was correlated with malignant characteristics of human HCC (clinical stages, recurrence, lymphatic metastasis, vascular invasion and serum AFP levels). HCC patients with high distribution of sympathetic and parasympathetic nervous fibers tended to have worse overall survival times compared to patients with low distribution of sympathetic and parasympathetic nervous fibers. This finding is in accordance with recently published data demonstrating that the infiltration of sympathetic and parasympathetic fibers promoted the development of prostate tumors [1]. And the innervation of autonomic nerves was also found in other tumors, such as breast cancer $[14,15]$, gastric cancer and so on
[16]. And it has been reported that the innervation was criti$\mathrm{cal}$ at all stages of gastric tumorigenesis and vagal innervation contributed to gastric tumorigenesis [2]. So we could infer that the nervous system could also accelerate the progression of HCC and high distribution of autonomic fibers indicates poor prognosis of HCC patients.

In our studies, the different expression of receptors for neurotransmitters in the liver cancer cells was readily observed. Using the available diagram, it was observed that most of HCC cells expressed adrenergic receptors and cholinergic receptors. Through the pie chart (Figure 2B), we can easily found that the receptors for neurotransmitters (adrenergic receptors $\beta 2$, $\alpha 1 \mathrm{~A}$ and cholinergic receptors $\alpha 7 \mathrm{nAChR}$ and $\mathrm{M} 1$ and $\mathrm{M} 3$ mAChRs) were expressed on most kinds of hepatoma cells, which implied the importance of these receptors. Particularly, as408, T127 and T421 derived from portal venous tumor emboli, which had high abilities of invasion and metastasis, showed a wide range of receptors expression. The cells (T420, T1115, and T1224) from HCC patients also exhibited the same feature. And these primary hepatic carcinoma cells all had high abilities of invasion and migration. Nonetheless, normal liver cells L02 showed the opposite receptors for neurotransmitters expression, which expressed few or single receptors for neurotransmitters. Maybe it was these differences that bring to the different characteristics of hepatoma cells. Through comparison of as408, MHCC-97H and HepG2, we found that they all had $\beta 2$ adrenergic receptors and $\mathrm{M} 3$ cholinergic receptors expression. But except the two receptors, as 408 also expressed $\mathrm{M} 1$ and $\alpha 7$ cholinergic receptors. The activation of these receptors could promote tumorigenesis and metastasis $[14,17,2]$, which confirmed the importance of these receptors. So it suggested that the different expression of receptors for neurotransmitters could indicate the capacity of invasion, migration or proliferation in different HCC cells. For example, activation of $\beta 2$ adrenergic receptor promoted breast cancer cell invasion and colon cancer growth $[18,19]$. Similarly, cholinergic receptor $\mathrm{M} 3$ could mediate cell proliferation and apoptosis in gastric tumors [20]. Nicotine promoted proliferation of human nasopharyngeal carcinoma cells by regulating a $7 \mathrm{nAChR}$ [17]. So it implied that the activation of these receptors could also contribute to the proliferation, invasion or apoptosis in hepatocellular carcinoma through their corresponding signaling pathways.

From recent studies, it was observed that $\beta 2$ adrenergic receptor, $\alpha 7, \mathrm{M} 1$ and $\mathrm{M} 3$ cholinergic receptors were widely studied in cancers, which contributed to the progression of different tumors. Combined with our radar map, it also supported that the $\beta 2$ adrenergic receptor and $\alpha 7, M 1$ and $M 3$ cholinergic receptors played important roles in hepatoma cells. Therefore these studies demonstrate that different kinds of hepatoma cells express multiple kinds of receptors for neurotransmitters and the cholinergic receptors $\alpha 7, \mathrm{M} 1$ and $\mathrm{M} 3$ and adrenergic receptor $\beta 2$ are most important in the progression of HCC.

In conclusion, the autonomic nervous system must have certain effects on HCC. Our studies illustrated the distribution 
of receptors for neurotransmitters in many kinds of hepatoma cells and indicated that activation of these receptors for neurotransmitters, especially $\beta 2$ adrenergic receptor and $\alpha 7, \mathrm{M} 1$ and $\mathrm{M} 3$ cholinergic receptors, may influence the development of HCC in many ways. Although the detailed mechanisms and more clinical data still need to study, our study provides some evidences for investigating the role of autonomic nervous system in HCC. In addition, our finding suggests that targeted interruption of autonomic signaling pathways may constitute a novel approach for prevention of HCC.

Acknowledgements: This work was supported by the National Natural Science Foundation of China (No. 81272224). Sincerely thanks for Professor Qian cheng, from the Institute of Pathology and Southwest Cancer Center, donating primary hepatic carcinoma cells. The authors report no conflicts of interest in this work.

\section{References}

[1] MAGNON C, HALL SJ, LIN J, XUE X, GERBER L et al. Autonomic nerve development contributes to prostate cancer progression. Science 2013; 341: 1236361. https://doi. org/10.1126/science.1236361

[2] ZHAO CM, HAYAKAWA Y, KODAMA Y, MUTHUPALANI S, WESTPHALEN CB et al. Denervation suppresses gastric tumorigenesis. Sci Transl Med. 2014; 6: 250ra115. https://doi. org/10.1126/scitranslmed.3009569

[3] ONDICOVA K, MRAVEC B. Role of nervous system in cancer aetiopathogenesis. Lancet Oncol 2010; 11: 596-601. https:// doi.org/10.1016/S1470-2045(09)70337-7

[4] CHENG K, XIE G, KHURANA S, HEATH J, DRACHENBERG CB et al. Divergent effects of muscarinic receptor subtype gene ablation on murine colon tumorigenesis reveals association of M3R and zinc finger protein 277 expression in colon neoplasia. Mol Cancer. 2014; 13: 77. https://doi. org/10.1186/1476-4598-13-77

[5] ESPANOL AJ, DE LA TORRE E, FISZMAN GL, SALES ME. Role of non-neuronal cholinergic system in breast cancer progression. Life Sci 2007; 80: 2281-2285. https://doi. org/10.1016/j.lfs.2006.12.017

[6] MASUR K, NIGGEMANN B, ZANKER KS, ENTSCHLADEN F. Norepinephrine-induced migration of SW 480 colon carcinoma cells is inhibited by beta-blockers. Cancer Res 2001; 61: 2866-2869.

[7] MOMI N, PONNUSAMY MP, KAUR S, RACHAGANI S, KUNIGAL SS et al. Nicotine/cigarette smoke promotes metastasis of pancreatic cancer through alpha7nAChR-mediated MUC4 upregulation. Oncogene 2013; 32: 1384-1395. https:// doi.org/10.1038/onc.2012.163

[8] GRYTLI HH, FAGERLAND MW, FOSSA SD, TASKEN KA, HAHEIM LL. Use of beta-blockers is associated with prostate cancer-specific survival in prostate cancer patients on androgen deprivation therapy. Prostate 2013; 73: 250-260. https:// doi.org/10.1002/pros.22564
[9] LEMESHOW S, SORENSEN HT, PHILLIPS G, YANG EV, ANTONSEN $S$ et al. beta-Blockers and survival among Danish patients with malignant melanoma: a population-based cohort study. Cancer Epidemiol Biomarkers Prev 2011; 20: 2273-2279. https://doi.org/10.1158/1055-9965.EPI-11-0249

[10] RABBEN HL, ZHAO CM, HAYAKAWA Y, WANG TC, CHEN D. Vagotomy and Gastric Tumorigenesis. Curr Neuropharmacol 2016; 14: 967-972. https://doi.org/10.2174/15 70159X14666160121114854

[11] SIEGEL RL, MILLER KD, JEMAL A. Cancer statistics, 2016. CA Cancer J Clin 2016; 66: 7-30. https://doi.org/10.3322/ caac. 21332

[12] SHAN J, SHEN J, LIU L, XIA F, XU C et al. Nanog regulates self-renewal of cancer stem cells through the insulin-like growth factor pathway in human hepatocellular carcinoma. Hepatology 2012; 56: 1004-1014. https://doi.org/10.1002/hep.25745

[13] ZHANG SH, WANG CJ, SHI L, LI XH, ZHOU J et al. High Expression of FLOT1 Is Associated with Progression and Poor Prognosis in Hepatocellular Carcinoma. PLoS One 2013; 8: e64709. https://doi.org/10.1371/journal.pone.0064709

[14] CHOY C, RAYTIS JL, SMITH DD, DUENAS M, NEMAN $J$ et al. Inhibition of beta2-adrenergic receptor reduces triple-negative breast cancer brain metastases: The potential benefit of perioperative beta-blockade. Oncol Rep 2016; 35: 3135-3142. https://doi.org/10.3892/or.2016.4710

[15] ISERI OD, SAHIN FI, TERZI YK, YURTCU E, ERDEM SR et al. beta-Adrenoreceptor antagonists reduce cancer cell proliferation, invasion, and migration. Pharm Biol 2014; 52: 1374-1381. https://doi.org/10.3109/13880209.2014.892513

[16] SHIN VY, JIN HC, NG EK, YU J, LEUNG WK et al. Nicotine and 4-(methylnitrosamino)-1-(3-pyridyl)-1-butanone induce cyclooxygenase-2 activity in human gastric cancer cells: Involvement of nicotinic acetylcholine receptor ( $\mathrm{AAChR}$ ) and beta-adrenergic receptor signaling pathways. Toxicol Appl Pharmacol 2008; 233: 254-261. https://doi.org/10.1016/j. taap.2008.08.012

[17] SHI D, GUO W, CHEN W, FU L, WANG J et al. Nicotine promotes proliferation of human nasopharyngeal carcinoma cells by regulating alpha7AChR, ERK, HIF-1alpha and VEGF/ PEDF signaling. PLoS One. 2012; 7: e43898. https://doi. org/10.1371/journal.pone.0043898

[18] PON CK, LANE JR, SLOAN EK, HALLS ML. The beta2adrenoceptor activates a positive CAMP-calcium feedforward loop to drive breast cancer cell invasion. FASEB J 2016; 30: 1144-1154. https://doi.org/10.1096/fj.15-277798

[19] WU WK, WONG HP, LUO SW, CHAN K, HUANG FY et al. 4-(Methylnitrosamino)-1-(3-pyridyl)-1-butanone from cigarette smoke stimulates colon cancer growth via betaadrenoceptors. Cancer Res.2005; 65: 5272-5277. https://doi. org/10.1158/0008-5472.CAN-05-0205

[20] WANG L, ZHI X, ZHANG Q, WEI S, LI Z et al. Muscarinic receptor $\mathrm{M} 3$ mediates cell proliferation induced by acetylcholine and contributes to apoptosis in gastric cancer. Tumour Biol 2015; 37: 2105-2117. https://doi.org/10.1007/s13277$\underline{015-4011-0}$ 